\title{
Girişimcilik Fırsatlarını Tanımanın Öncülleri Olarak Risk Alma ve Ön Bilgi: Girişimci Adayları Üzerine Bir Araştırma ${ }^{1}$
}

Araştırma Makalesi /Research Article

\author{
Gaye ONAN ${ }^{2}$ \\ Utku GÜĞERÇİN ${ }^{3}$
}

ÖZ: Fırsat tanıma kavramı günümüzde, girişimcilik faaliyetleri için temel bir yapıtaşı olarak ele alınmaya başlanmıştır. Dolayısıyla girişimcilik firsatlarının nasıl tanındığını ve bireysel farklılıkların bu firsatların tanınmasında nasıl bir rol oynadı̆̆ını anlamak önem kazanmaktadır. Ancak alanyazında girişimcilik firsatlarını tanımanın öncüllerine ilişkin bir görüş birliği olmadı̆̆ı, ulusal yazında ise girişimcilik firsatlarını tanımanın sınırlı sayıda çalışmada ele alındı̆̆ görülmüşür. Bu noktalardan hareketle çalışmanın amacı, Bilişsel teoriden ve Avusturya iktisat teorisinden yola çıkarak, girişimci adaylarının ön bilgilerinin ve risk alma eğilimlerinin, girişimcilik firsatlarını tanıma düzeyleri üzerindeki etkisini araştırmaktır. Çalışma kapsamında, girişimcilik firsatlarını tanıma düzeyinin eğitim durumuna göre farklılı gösterip göstermediği de incelenmiştir. Araştırmada kullanilan veriler, KOSGEB'in Adana ve Mersin illerindeki girişimcilik ĕgitimlerine katılan girişimci adaylarından anket yoluyla temin edilmiştir. Çoklu doğrusal regresyon yöntemi ile gerçekleştirilen analizler sonucunda, girişimcilerin ön bilgileri ve risk alma eğilimlerinin, girişimcilik firsatlarını tanıma üzerinde pozitif yönde etkili olduğu tespit edilmiştir. Ayrıca girişimcilik firsatlarını tanıma düzeyinin eğitim durumuna göre anlamlı bir farklılık göstermediği bulgulanmıştır.

Anahtar Kelimeler: Girişimcilik Fırsatlarını Tanıma, Ön Bilgi, Risk Alma, Girişimcilik

Jel Kodu:M13

\section{Risk-Taking and Prior-Knowledge as the Antecedents of Entrepreneurial Opportunity Recognition: A Study on Nascent Entrepreneurs}

ABSTRACT: Today, opportunity recognition considered as a constituent of entrepreneurship efforts. Accordingly, the questions of how entrepreneurial opportunities are recognized and how the personal differences play a role in opportunity recognition are of the essence. However, there is no consensus in the literature regarding the antecedents of entrepreneurial opportunities. Moreover, entrepreneurial opportunity recognition analyzed in a limited number of studies in the national literature. The aim of this study, therefore, is to examine the impact of nascent entrepreneurs' prior-knowledge and their tendency toward risk-taking on entrepreneurial opportunity recognition based on cognitive theory and Austrian economics theory. In the context of the study, examined whether entrepreneurial opportunity recognition level differs based on education level. Survey method used to gather data from nascent entrepreneurs, who participated in the entrepreneurship training programs. Results of the multiple linear regression method revealed that prior-knowledge and tendency toward risk-taking found to have a positive effect on entrepreneurial opportunity recognition. Additionally, entrepreneurial opportunity recognition was not found to differ based on education level.

Keywords: Opportunity Recognition, Prior-Knowledge, Risk-Taking, Entrepreneurship

Jel Code: $M 13$

Geliş Tarihi / Received: 25/06/2020

Kabul Tarihi / Accepted: 05/01/2021

\footnotetext{
${ }^{1}$ Bu makale, 02-04 Mayıs 2019 tarihleri arasında düzenlenen 18.Uluslararası İşletmecilik Kongresi’nde sunulan "Fırsat Tanımanın Öncülleri Olarak Risk Alma ve Ön Bilgi: Girişimci Adayları Üzerine Bir Araştırma” başlıklı tam metin bildirinin genişletilmiş halidir.

${ }^{2}$ Dr. Öğretim Üyesi, Mersin Üniversitesi, gayeonan@mersin.edu.tr, orcid.org/ 0000-0001-6302-5211

${ }^{3}$ Doç. Dr., Adana Alparslan Türkeş Bilim ve Teknoloji Üniversitesi, ugugercin@atu.edu.tr, orcid.org/ 0000-00027667-6256
} 


\section{Giriș}

Girişimcilik, uzun yıllardır işletmeden iktisada, sosyal antropolojiden psikolojiye kadar pek çok farklı alanda incelenmektedir. Girişimciliğe olan bu ilgide; girişimlerin büyüme, kalkınma, istihdam yaratma gibi ekonomik ve sosyal katkıları yanında, girişimcilerin elde ettiği sosyal, ekonomik ya da psikolojik faydalar da etkilidir (Henrekson, 2007: 1). Söz konusu olumlu etkilere bağl olarak araştırmacılar, girişimcilik sürecini ve özellikle bu süreçteki başat aktör olan girişimcilerin özelliklerini açıklamaya çalışmışlardır ve başarılı girişimcilerin hangi özellikleriyle diğerlerinden ayrıldıkları sorusu, pek çok araştırma için temel oluşturmuştur (Bygrave ve Hofer, 1992; Kuratko, 2016; Littunen, 2000).

Girişimciler temel olarak; bilişsel, davranışsal ve psikolojik özellikleri çerçevesinde ele alınmışlardır (Carsrud ve Johnson, 1989; Baron, 2007a). Zaman içerisinde bilişsel özellikler arasında yer alan fırsat tanıma, girişimcilik sürecindeki ilk aşama ve hatta temel unsur (Venkataraman, 1997: 123; Shane, 2000: 448) olarak kabul edilmiş ve girişimcinin başarısı için anahtar nitelikte olan bir faktör olarak değerlendirilmeye başlanmıştır (Ozgen ve Baron, 2007: 176). Bygrave ve Hofer (1992: 14) girişimcilik sürecinin firsatların algılanması ile başladığını, girişimlerin kurulmasının dahi bu firsatların değerlendirilmesine bağlı olduğunu ifade etmiştir. Girişimcilik sürecinin temel olarak iki adımdan oluştuğu; ilk adımın firsatı tanıma, ikinci adımın ise fırsatın değerlendirilmesi olduğu göz önüne alındığında, girişimcilik fırsatlarını tanımanın önemi daha açık şekilde görülmektedir.

Girişimcilik fırsatlarını tanıma süreci farklı yazarlar tarafından geliştirilen çeşitli teoriler, modeller ve bakış açılarıyla açıklanmaya çalışılmıştır. Bu modeller ve teoriler, bilişsel teoriden iktisadi modellere kadar çeşitlilik göstermekte, farklı disiplinler kapsamındaki farklı varsayımlara dayanmaktadır (Ardichvili vd., 2003; Shane, 2000). Girişimcilik firsatlarını tanıma kavramı ile birlikte bu kavramın öncülleri ve ardılları, dünyanın farklı bölgelerindeki akademisyenler ve uygulayıcılar tarafından artan bir ivme ile tartışılmaktadır. Bu araştırmalar neden özellikle bazı bireyler girişimcilik firsatlarını tanımlayabiliyor iken diğerlerinin bunu başaramadığı üzerinde durmaktadır. Ancak alanyazında girişimcilerin ya da girişimci adaylarının firsatları nasıl tanıdığ konusunda bir fikir birliği oluşmadığı görülmektedir (Wang vd., 2013: 250). Türkiye'de ise girişimcilerin ya da girişimci adaylarının firsat tanıma düzeylerini etkileyen faktörlerin tespitine yönelik çalışmalar incelendiğinde sınırlı sayıda çalışmaya rastlanmıştır. Söz konusu çalışmalardan Karabey ve Bingöl'ün (2010) araştırmasında, firsat kavramı girişimcilik açısından ele alınmış ve firsat tanıma olgusu kavramsal olarak incelenmiştir. Kalfaoğlu ve Öğe'nin (2018) araştırmasında ise fırsat tanıma ile polikronisite ${ }^{4}$ ilişkisi tartışılmıştır. Özkul ve Dulupçu (2014) ise girişimcilik

\footnotetext{
${ }^{4}$ Polikronisite: Bireyin aynı anda iki veya daha fazla görevi yürütmeyi tercih etmesi ve bu tercihin bu görevleri yerine getirmek için en doğrusu olduğuna inanması (Bluedorn, 2002: 51).
} 
Uluslararası Ekonomi ve Yenilik Dergisi, 7 (1) 2021, 1-20

fırsatlarını tanımanın öncüllerine odaklanarak, üretim sektöründeki fırsat türlerini ve bu türler üzerinde etkili olan bireysel, firmaya özgü ve sektörel faktörleri aynı anda incelemiş ve girişimcilik firsatlarına yönelik bir sınıflandırma yapmışlardır.

$\mathrm{Bu}$ araştırmanın amacı, bilişsel teoriden ve Avusturya iktisat teorisinden hareketle, yurt dışında önceki araştırmalarda girişimcilik firsatlarını tanıma üzerinde etkili olduğu tespit edilen girişimcilerin ön bilgi düzeylerinin ve risk alma eğilimlerinin, girişimcilik fırsatlarını tanıma düzeyleri üzerindeki etkilerinin belirlenmesidir. Çalışma kapsamında, girişimcilik fırsatlarını tanıma düzeyinin eğitim durumuna göre farklılık gösterip göstermediği de incelenmiştir.

Ön bilgi ve girişimcilik fırsatlarını tanıma ilişkisinin teorik çerçevesi, Avusturya iktisat teorisine dayanmaktadır. Bu teori, fırsat tanıma sürecinde girişimcilerin bilgi birikimlerine odaklanarak, bireyler arası bilgi farklılıklarının firsat tanımadaki etkisine vurgu yapmaktadır. Risk alma eğilimi ve fırsat tanıma ilişkisinin teorik çerçevesi ise bilişsel teoriye dayanmaktadır. Teoriye göre bireylerin sahip oldukları bilgiler ve bu bilgileri nasıl yorumladıkları risk algılarını etkilemektedir.

Çalışmada, öncelikle girişimcilik ve fırsat tanıma kavramlarına ilişkin literatür incelemesi yapılmış daha sonra girişimcilik firsatlarını tanımanın öncülleri olarak ele alınan faktörlerden ön bilgi ve risk alma kavramları açıklanmıştır. Ardından, yöntem bölümünde, Avusturya iktisat teorisi ve bilişsel teori temel alınarak, girişimci adaylarının sahip olduğu ön bilgi ve risk alma eğilimlerinin girişimcilik fırsatlarını tanıma düzeyleri üzerindeki etkisi analiz edilmiştir. Çalışmada kullanılan veriler Adana ve Mersin'de KOSGEB Uygulamalı Girişimcilik Eğitimi'ne katılan kursiyerlerden elde edilmiş ve bu verilerin analizinde SPSS paket programı kullanılmıştır. Çalışmanın sonuç kısmında ise analiz sonuçları yorumlanmış, araştırmacılara ve uygulayıcılara yönelik öneriler sunulmuştur.

\section{Kavramsal Çerçeve}

\subsection{Firsat Kavramı ve Firsat Tanıma}

Girişimcilik ile ilgili akademik araştırmalar incelendiğinde, farklı bilim dallarının farklı noktalara vurgu yaptığı görülmektedir. Örneğin iktisat bilimi girişimciliği tanımlarken, üretim faktörlerinin ekonomik değer yaratmasından bahsetmekte, psikoloji bilimi ise güdüler ve ihtiyaçlardan yola çıkarak girişimcinin insani özelliklerine vurgu yapmaktadır. Girişimcilik kavramının öncüsü kabul edilen Cantillon (1755) ve daha sonrasında Knight (1921) girişimciliği kavramsallaştırırken risk ve belirsizliğe vurgu yapmışlardır (Karadal, 2014: 5). Her iki araştırmacının da girişimciliğe dair ortak tanımı "belirsizlik ve risk altında kar elde etmeye çalışarak faaliyet gösterme" olarak ifade edilebilir. Schumpeter (1934: 66) ise girişimciliğe "yenilik" bakış açısını kazandırarak, bu konudaki araştırma ve tanımlamaların seyrini değiştirmiştir. Ona göre "yeni ürünler, yeni hizmetler, yeni hammadde kaynakları, yeni üretim yöntemleri, yeni pazarlar ve yeni örgütlenme biçimleri için yeni faktör birleşimlerini” bir araya getiren bireyler 
girişimci olarak tanımlanmaktadır. Girişimcilik her ne kadar yenilik kavramı ile bütünleşmiş gibi görünse de araştırmacılar girişimcilik sürecinde firsat tanımaya da vurgu yaparak; yalnızca girişimin hayata geçirilmesinin değil, aynı zamanda yeni girişimcilik firsatlarının tanınmasının da girişimcilik süreci için önemini vurgulamışlardır (Stevenson vd.,1985; Ardichvili vd., 2003, Baron,2007b).

Fırsat tanıma konusu, 2000'li yıllara doğru araştırmacılar tarafından girişimcilik sürecinin anlaşılması için üzerinde önemle durulan bir konu haline gelmiştir. $\mathrm{Bu}$ bağlamda, Bygrave ve Hofer (1992: 14) girişimciyi, "bir firsatı algılayan ve onu takip etmek için bir organizasyon yaratan kişi" olarak tanımlamıştır. Shane ve Venkataraman'a göre de (2000:218) "girişimcilik, gelecekteki mal ve hizmetleri yaratma fırsatlarını kim, nasıl ve neyin etkilediğinin araştırıldığı, değerlendirildiği ve sonunda bu fırsatlardan faydalanıldığı bir çalışmadır”. Girişimcilik ile ilgili tanımlarda fırsat kavramının daha fazla ön plana çıkmaya başlaması; fırsat algılama, tanıma, değerlendirme gibi kavramlara yer verilmesi, girişimciliğin günümüzde firsat olgusu çevresinde gelişen bir kavram olduğunu vurgulamaktadır (Karabey ve Bingöl, 2010: 10).

Kirzner (1997) en temel şekliyle, "fırsat" olarak adlandırılabilecek şeyi, "kesin olarak tanımlanmamış bir pazar ihtiyacı" veya "kullanılmayan kaynaklar" olarak açıklamıştır. Shane ve Venkataraman (2000: 220), yeni mal ve hizmetlerin üretim maliyetlerinden daha fazla satılabileceği durumların da firsat olduğunu öne sürmüşlerdir. Schumpeter (1934) ise fırsat1, "eldeki kaynakların yaratıcı bir birleşimi ile üstün bir değer meydana getirerek pazarın ihtiyacını karşılama" olarak tanımlamıştır. Fırsat terimi için birçok tanım önerilmiş olsa da, çoğu tanım üç temel özelliği içerir (Baron, 2004: 52). Bu özellikler; potansiyel ekonomik değer (yani, kar elde etme potansiyeli), yenilikçilik (daha önce bulunmayan bazı ürün, hizmet, teknoloji vb.) ve arzu edilebilirliktir (örneğin, yeni ürün veya hizmetin toplumda ahlaki ve yasal olarak kabul edilebilirliği). Burada önemli olan nokta, girişimcinin fırsatın varlığından haberdar olabilmesi yani onu tanıma kapasitesidir. Çünkü girişimcilik süreci temel olarak iki adımdan oluşur: ilk adım fırsatı tanıma, diğeri ise fırsatı değerlendirmedir. Girişimcinin firsatı tanıyabilmesi ve değerlendirebilmesi ona rekabet üstünlüğü sağlayarak kar elde etmenin yolunu açacaktır.

Girişimcilerin başarısı için temel özellik olarak ifade edilen firsat tanıma (Ucbasaran vd., 2000: 168), "bireylerin değer yaratma potansiyeli taşıyan her türlü karşılanmamış ihtiyaç ve piyasa boşluklarını algılamak ve firsat olarak adlandırılabilecek forma dönüştürebilmek için gerçekleştirdiği faaliyetler dizisi" olarak tanımlanmıştır (Karabey ve Bingöl, 2010: 20). Diğer bir tanıma göre ise firsat tanıma; girişimcilerin yeni iş, pazar ve teknolojiler oluşturmak ve geliştirmek için potansiyel fırsatları takip ettiği, tanıdığı ve keşfettiği bir süreçtir (Shane ve Venkataraman, 2000: 220). Bazı araştırmacılar bu sürecin birbiri ile bağlantılı 5 adımdan oluştuğunu öne sürmüşlerdir (Ardichvili vd, 2003; Baron ve Ensley, 2006). İlk adım, başlangıç adımıdır ve bu adımda dış çevredeki 
değişiklikler, kesin olarak tanımlanmamış pazar ihtiyaçları veya henüz kullanılmamış kaynaklar belirlenir. İkinci adım, fırsat geliştirme adımıdır. Burada temel fikir daha ayrıntılı hale gelir ve potansiyel bir iş fikri ortaya çıkmaya başlar. Üçüncü adım, fırsat tanıma adımıdır, bu adım firsatların algılanması, keşfi veya yaratılması ve fikri, iş kavramına dönüştürme aşamasıdır. Dördüncü adımda firsat değerlendirilir, yani bir iş modeli hazırlanarak iş kavramı, finansal planlama ve kaynak gereksinimleri ortaya konur, analiz yapılarak, değer yaratılıp yaratılmayacağı ve karın sağlanıp sağlanmayacağı belirlenir. Beşinci adım olan son adımda ise firsat gerçekleştirilir, bu noktada tüm adımlar olumlu değerlendirilirse, fırsattan yararlanılacak ve yeni bir iş kurulacaktır.

Girişimcilik süreci, fırsatların algılanması ile başlar ve bu firsatları değerlendirecek organizasyonların yaratılması ile ilgili tüm işlevleri, faaliyetleri ve eylemleri içerir (Bygrave ve Hofer, 1992: 14). Stevenson vd. (1985), yeni işletmeler için doğru firsatları belirlemenin ve seçmenin, başarılı bir girişimcinin en önemli yetenekleri arasında olduğunu ifade etmiştir (Ardichvili vd., 2003: 105). Baron'a (2007b: 104) göre de girișimcilik "firsatların tanınması ve bu firsatlar ile ilgili harekete geçilmesi" ile ilgilidir. Bir girişimcinin doğru firsatları tanıma ve seçme becerisine sahip olması özellikle yeni işletmeler için zorunludur. Girişimci bireyin kar getirecek firsatları tanıma kabiliyeti, diğer rakiplerin göremediği potansiyel firsatları önceden fark etmesini ve kullanmasını sağlayabilir. Girişimcilik fırsatlarını tanımak; genellikle kar, büyüme ve rekabetçi konumlandırmada işletme için rekabet avantajı sağlayabilir.

Her ne kadar araştırmacılar girişimcilerin fırsatları tanıması ve belirlemesi ile ilgili çalışmalar yapmış olsa da bu konuya ilişkin görüş birliği sağlanamadığı görülmektedir. Bilim insanları arasında bireylerin firsatları nasıl tanıdığ 1 konusunda büyük bir anlaşmazlık vardır (Wang vd., 2013: 250). Firsat tanıma süreci son yıllarda farklı yazarlar tarafindan geliştirilen çeşitli teoriler, modeller ve bakış açılarıyla ile açıklanmaya çalışılmıştır. Bu modeller ve teoriler, "Bilişsel Psikoloji”den “Avusturya İktisat Teorisi”ne kadar çeşitli disiplinlere yönelik farklı varsayımlara dayanmaktadır (Ardichvili vd., 2003; Shane, 2000).

Talep ve arzın sürekli dengede olduğunu, pazardaki tüm aktörlerin pazar koşulları hakkında mükemmel bir bilgiye ve gelecekte ortaya çıkabilecek durumlar hakkında kusursuz bir öngörüye sahip olduğunu ve sonuç olarak bir girişimci için firsatların ve firsat algısının olmadığını (Renko vd.,2012:6) iddia eden Neoklasik teoriye cevap olarak geliştirilen Avusturya iktisat teorisi, birçok örgütsel çevrede girişimcilik araştırmasına önderlik eden ekonomik bir yaklaşım olarak tanınmıştır (Venkataraman 1997; Shane 2000). Avusturya iktisat teorisi piyasaların dengede ve tam rekabet içinde değil, dinamik bir rekabet içinde olduğunu ve sabit bir dengesizlik durumunun söz konusu olduğunu öne sürmektedir. Bu teoriye göre pazardaki firsatlar görünür değildir ve pazardaki dengesizlik durumu firsatları yaratmaktadır (Wang vd., 2013: 251). Ayrıca bu görüş bireylerin tüm firsatları tanıyamayacağını varsaymaktadır (Renko vd., 2012: 7). 
Avusturya iktisat teorisi iki Avusturya ekonomisti Schumpeter ve Kirzner'in düşüncelerini temel almaktadır (Venkataraman, 1997). Bu iki düşünürün fikirleri arasında bir takım farklılıklar vardır. Schumpeter (1934) girişimcilik firsatlarının "yaratıcı yıkım" sürecinin sonucu olarak ortaya çıktığını öne sürmektedir. Buna göre girişimciler fırsatları keşfetmezler, ekonomide meydana gelen yeniliğin sağladığı teknolojik değişimi kullanarak firsatları yaratırlar (Dutta ve Crossan, 2005: 429). Schumpeteryan görüşün aksine Kirzner (1997), girişimcinin sahip olduğu bilgiden veya bilgi asimetrilerinden yararlanarak firsatları keşfettiğini öne sürmektedir (Dutta ve Crossan, 2005: 429-430). Buna göre piyasada firsatlar, sınırlı sayıdaki girişimci adayından oluşan bir alt küme tarafından keşfedebilir ve değerlendirebilir. $\mathrm{Bu}$ iki farklı yaklaşım konu ile ilgili gerçekleştirilen araştırmalarda da göze çarpar; Shane (2000) firsatların keşfedildiğini, Baron (2004,2006) tanındıklarını, Sarason vd. (2005) inşa edildiklerini, Krueger (2000) algılandıklarını ve inşa edildiklerini öne sürmektedir. $\mathrm{Bu}$ açıklamalardan hareketle Avusturya iktisat teorisi firsat tanımada girişimcilerin bilgi birikimlerini temel almakta ve bireyler arası bilgi farklılıklarının firsat tanımadaki etkisine dikkat çekmektedir.

Bilişsel teori ise, bireylerin davranışlarının açıklanmasında düşünce, beklenti, tutum gibi içsel süreçleri temel alarak, bireylerin benzer uyaranlar karşısında neden farklı tepkiler gösterdiğini açıklamaya çalışır (Bilgin, 2016: 61). Bilişsel psikolojiye dayanan bilişsel teori, her bireyin zihinsel yapısının bir girişimcilik fırsatını tanımlama ve kullanma becerisiyle nasıl ilişkili olduğunu açıklamaya yardımcı olabilir. Girişimci bireylerin bilişsel mekanizmalarının karar alma süreçlerinde etkili olduğu bilinmektedir (Tomak, 2011: 85). Bilişsel teoriye göre bir girişimci kullandığı bilişsel mekanizmaları sayesinde sıradan olaylar içerisindeki farklılıkları görebilir ve bu sayede firsatları tespit edebilir (Tomak, 2011: 88). Bu teoriye göre girişimcilik firsatlarını tanıma, girişimcinin bilişsel özelliklerine bağlıdır. Bir pazar ihtiyacının algılanması veya ayrı olarak bir ürün, hizmet veya pazarın ihtiyacını karşılayacak diğer faktörlerin algılanması yeterli değildir. Bir girişimcilik fırsatını tanımak için bu ikisinin bilişsel olarak birbirine bağlanması ya da bütünleştirilmesi gerekmektedir (Renko vd., 2012: 7). Mevcut araştırmalar, girişimcilik fırsatlarını tanıma kabiliyetlerinin farklılık gösterdiğini, çünkü her bireyin farklı bilgi birikimine, farklı bilişsel mekanizmalara ya da sezgilere sahip olduğunu ortaya koymaktadır (Baron, 1998).

Bireylerin bilişsel mekanizmalarının işleyişini sağlayan farklı bilişsel önyargılar ya da sezgiler, bireylerin sahip oldukları bilgileri ve bu bilgileri nasıl yorumladıklarını ve dolayısıyla risk algısını etkilemektedir (Busenitz ve Barney, 1997). Tomak (2011), bilişsel teori çerçevesinde bireyin algıladığı riskin davranışlarına yön verdiğini ifade etmektedir. Simon vd.(2000:113), girişimcinin yeni bir girişimle ilgili risk algısı düşük ise yeni bir iş kurma olasılığının arttığını belirlemişlerdir. Girişimcilik literatüründeki çok sayıda araştırma, girişimcilerin riskli olmasına rağmen yeni girişimler başlatma nedenlerini ele almaktadır. $\mathrm{Bu}$ 
Uluslararası Ekonomi ve Yenilik Dergisi, 7 (1) 2021, 1-20

konudaki araştırma bulguları yeni girişimlerin performansının yetersiz ve tüm girişimlerin yarısından fazlasının 5 yıl içinde başarısız olmasına rağmen girişimcilerin iş durumlarını değerlendirmede daha iyimser olduklarını ileri sürmektedir. $\mathrm{Bu}$ da girişimcilerin risk alma eğiliminde olduğu varsayımına yol açmaktadır (De Carolis ve Saparito, 2006: 50).

Mitchell vd. (2002: 94) girişimcilerin firsatları tanımasına temel olan unsurları iki ana başlık altında toplamıştır: girişimcinin sahip olduğu ön bilgi düzeyi ve bilişsel özellikler. Buna dayanarak girişimcilik firsatlarını tanımanın girişimcinin edindiği bir dizi bilgi kaynağından ve sahip olduğu bilişsel özelliklerin yansıması olan risk alma eğiliminden etkilendiği söylenebilir. Tüm bunlardan hareketle bu çalışmada, geçmiş çalışmalardan yola çıkılarak ve Avusturya iktisat teorisi ve bilişsel teori temel alınarak girişimcilik fırsatlarının tanınması sürecinde, ön bilgi ve risk alma eğiliminin firsat tanıma üzerindeki rolü araştırılmıştır.

\section{2. Ön Bilgi}

Girişimciler, girişimcilik firsatlarının tamamını aynı şekilde tanımlayamamakta ve değerlendirememektedir çünkü herkesin eğitimi, bilgi birikimi ve dünyayı algılama şekli farklıdır (Aksay ve İplik, 2014). Shane ve Venkataraman'a göre (2000: 222) ön bilgi (prior knowledge) "bireyin firsat tespiti sürecine aracı olan bilgileri ifade eder". Bu bilgiler, örneğin; mevsimsel değişimler veya malların kalitesi hakkındaki bilgi olabilir. Venkataraman (1997: 122) bireylerin sahip oldukları bilgilerle girişimcilik firsatlarını tanıdıklarını ve bu nedenle mevcut fırsatların tanınması için yararlı bilgiye sahip olmaları gerektiğini söylemektedir. Bir insanın yaşamı boyunca edindiği tecrübeler ve aldığı eğitim, dolayısıyla sahip olduğu bilgi birikimi, kişinin girişimcilik firsatlarını tespit etmesine ve bu fırsatların sahip olduğu iş potansiyelinin farkına varmasına yardımcı olabilir. Ön bilgi, girişimcilik firsatlarını tanıma süreci için eşit öneme sahip üç unsur içermektedir (Shane, 2000: 452). Bu unsurlar; hangi pazara girileceği kararını etkileyen pazar hakkındaki ön bilgi; pazarda faaliyet gösterme yolları ile ilgili ön bilgi ve tüketici ihtiyaçları ve müşteri memnuniyeti hakkındaki ön bilgi şeklinde siralanmaktadir.

Ronstadt'a (1988: 33) göre, ön bilgiler girişimcilik firsatlarını tanımanın önemli bir unsurudur, çünkü her bir bireyin mevcut bilgisi bir "bilgi koridoru" yaratır ve bu koridor yeni bilgilerin anlaşılması, analiz edilmesi ve kullanılması için özel yollar sağlar. Bilgi koridoru bireyin sahip olduğu geçmiş bilgiler sayesinde oluşur ve bireyin belirli girişimcilik firsatlarını görmesine yol açabilir (Shane, 2000: 452). Buna göre bir girişimcinin sahip olduğu ön bilgi, girişimci olamayanlara göre firsatları daha iyi tanımalarına yardımcı olur (Venkataraman, 1997: 122; Shane ve Venkataraman, 2000: 222). Shane (2000: 452) girişimcinin yalnızca mevcut bilgisine paralel olan firsatları tanıdığını ve bu durumun yanlış fırsatların tanımasını veya seçmesini, dolayısıyla başarısız olma ihtimalini azalttığını öne sürmüştür. Konu ile ilgili gerçekleştirilen araştırmalar ön bilgi ile girişimcilik fırsatlarını tanıma arasındaki ilişkiyi ortaya koymaktadır; Ko ve Butler'ın (2006) 
araştırması, yüksek teknoloji girişimcisi için ön bilgiler ile girişimcilik fırsatlarının tespiti arasındaki ilişkinin daha güçlü olduğunu ortaya koymuştur. Shepherd ve DeTienne ise (2005) müşteri problemleri ile ilgili sahip olunan ön bilginin daha çok girişimcilik fırsatının tanınmasına yol açtığını ortaya koymuştur. Hajizadeh ve Zali (2016) de girişimcinin sahip olduğu ön bilginin girişimcilik fırsatlarını tanıma üzerinde pozitif bir etkisi olduğu sonucuna varmıştır. Ardichvili vd. 'nin (2003) çalışmasında ise girişimcinin sahip olduğu ön bilgi, iş firsatlarını tanıma öncüllerinden biri olarak kabul edilmiştir. Shane (2000) de çalışmasında ön bilgilerin girişimciye firsatları daha iyi tanıma kapasitesi sağladığını öne sürmüştür.

Girişimcinin sahip olduğu ön bilgi, karlı iş firsatlarının tanınması açısından bireyler için büyük bir avantaj olarak kabul edilir. Bir girişimcinin önceden edindiği bilgi, ihtiyaç duyulduğunda yeni bilgileri yorumlama, anlama ve kullanma yeteneklerini etkiler. Nitekim Hills ve Shrader (1998) girişimcilerin başarılı iş fikirlerinin, müşteriler ve pazar hakkında daha önceden bilgi sahibi olmasından kaynaklandığını ifade etmektedir. Bu doğrultuda iş fikri, piyasadaki belirli bir ihtiyaca cevap verme ihtiyacı ile tetiklenir.

\subsection{Risk Alma}

Girişimcilik sürecini anlayabilmek açısından girişimcilerin karar verme mekanizmasını etkileyen bilişsel faktörlerin bilinmesi önemlidir. Bilişsel teoriye göre bireyin algıladığı risk davranışlarına yön vermektedir, bu nedenle firsatları fark etmede ve ticarileştirmede girişimcinin risk algılamasının önemi büyüktür (Tomak, 2011: 89). Sarasvathy vd. (1998: 210) başarılı girişimcilerin başkalarının yalnızca risk olarak algıladığı durumlardaki firsatları gören bireyler olduğunu belirtmişstir. Bireysel girişimcilerin ortak özelliklerine ilişkin çalışmalar, girişimcilerin risk alma eğiliminde kişiler olduğunu ortaya koymakta ve günümüzde girişimcinin risk alma eğilimi bilişsel ve çevresel faktörler ile açıklanmaya çalışılmaktadır. Çünkü girişimcilik firsatlarını tanımada ve değerlendirmede girişimcinin sahip olduğu risk algısı diğer bireylerden farklılık göstermektedir (Tomak, 2011: 89).Bununla beraber girişimci bireylerin motivasyon kaynaklarını inceleyen araştırmalar girişimciliğin başarı için risk almaya isteklilik gibi kaynaklardan beslendiğini bulgulamışlardır (Kalkan ve Kaygusuz, 2012: 4).

Bir girişimciyi diğer insanlardan ayıran özelliklere odaklanan çalışmalar incelendiğinde, bu çalışmaların bazı ortak nitelikler etrafında toplandığı görülmektedir. Buna göre bir girişimci; dürüstlük, güvenilir olma, iyimserlik gibi bir takım kişisel değerlere, kişilerarası iletişim becerilerine ve sosyal ilişkilere, rekabetçi olma, kendine güvenme, risk alma ve hedefe odaklanma gibi özelliklere sahiptir. Krueger ve Dickson (1994) çalışmalarında kendine güvenen bireylerin daha fazla firsat tanıma eğiliminde olduklarını ve daha fazla risk almaya yatkın olduklarını ortaya koymuştur. Lunnan vd. (2006)'nin çalışmasına göre eğer bir birey girişimcilik firsatlarını tanıma özelliğine sahipse ve risk almaktan 
Uluslararast Ekonomi ve Yenilik Dergisi, 7 (1) 2021, 1-20

çekinmiyorsa yeni bir iş başlatma olasılığ $1 \% 45$ 'tir. Ancak eğer bir birey risk almazsa ve firsatları tanıyamıyorsa yeni bir iş başlatma olasılığı sadece \%10'dur. Özkul ve Dulupçu (2014)'ya göre ise, Schumpeteryen firsatların kullanımı girişimcilerin risk alma eğilimi ile pozitif yönde ilişkilidir. Risk alma eğilimindeki azalmaya bağlı olarak da Kirzneryen firsatların kullanımı artmaktadır.

\section{Yöntem}

\subsection{Araştırma Modeli ve Hipotezleri}

$\mathrm{Bu}$ araştırmada; Avusturya iktisat teorisi ve bilişsel teori temel alınarak, kavramsal çerçeve bölümünde belirtilen geçmiş çalışmalardan hareketle ön bilgi ve risk alma eğiliminin girişimcilik firsatlarını tanıma üzerindeki etkisi incelenmiştir. Oluşturulan araştırma modelinde; ön bilgi ve risk alma bağımsız değişkenler, girişimcilik firsatlarını tanıma ise bağımlı değişkendir. Araştırma modeli, Şekil 1'de görüldüğü gibidir.

Şekil 1: Araştırmanın Modeli

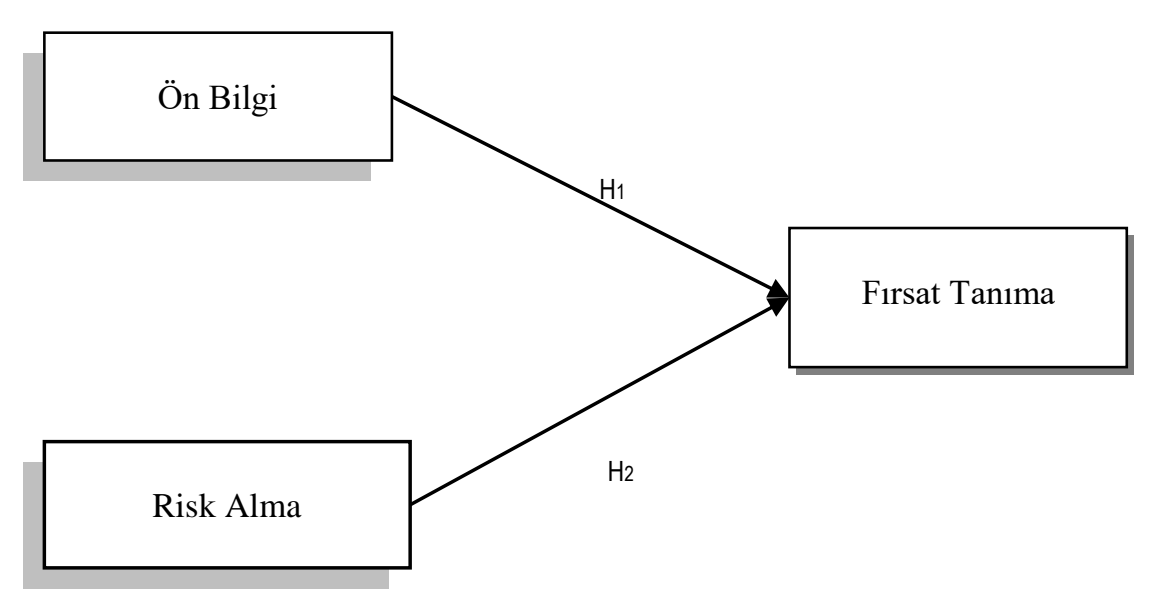

Araştırma modeli kapsamında, girişimcinin sahip olduğu ön bilgi ve risk alma eğilimi ile girişimcilik fırsatlarını tanıma arasında pozitif yönlü ilişkilerin olduğu varsayılmıştır. Ön bilgi ve girişimcilik firsatlarını tanıma ilişkisini Avusturya iktisat teorisi, risk alma eğilimi ve girişimcilik fırsatlarını tanıma ilişkisini ise bilişsel teori açıklamaktadır. İlgili teorilerden hareketle oluşturulan iki hipotez ile birlikte, girişimcilik fırsatlarını tanımanın eğitim durumuna göre farklılık gösterip göstermediğine yönelik olarak oluşturulan üçüncü hipotez aşağıdaki şekilde oluşturulmuştur:

$H_{1}$ : Ön bilgi ile girişimcilik firsatlarını tanıma arasında pozitif yönlü ve istatistiki olarak anlamlı bir ilişki bulunmaktadır.

$\mathrm{H}_{2}$ : Risk alma eğilimi ile girişimcilik firsatlarını tanıma arasında pozitif yönlü ve istatistiki olarak anlamlı bir ilişki bulunmaktadır.

$H_{3}$ : Girişimcilik firsatlarını tanıma, eğitim durumuna göre farklılık göstermektedir. 


\subsection{Verilerin Toplanması Süreci ve Örneklem}

Araştırmada kullanılan veriler, anket yöntemi kullanılarak elde edilmiştir. Araştırma evreni Türkiye'deki girişimci adaylarından, hedef kitlesi ise Adana ve Mersin illerinde, Küçük ve Orta Ölçekli İşletmeleri Geliştirme ve Destekleme İdaresi Başkanlığı (KOSGEB) tarafından gerçekleştirilen uygulamalı girişimcilik eğitimlerine katılan kursiyerlerden oluşmaktadır. Araştırma kapsamında, eğitimlere katılan toplam 250 girişimci adayına, kolayda örnekleme yöntemi ile anket formu dağıtılmıştır. Ancak “Ön Analizler” başlı̆̆ı altında belirtildiği üzere, 144 anket analize uygun görülmüştür. Faktör analizi için örneklem büyüklüğünün toplam ifade sayısının 10 katına ulaşması tavsiye edilmekte (Kline, 2013: 179), farklı bir kaynakta ise örneklem büyüklüğünün anketteki toplam ifade sayısının en az 5 katı olması önerilmektedir (Hair vd., 2005). Bu araştırmada kullanılan anket formundaki ifadelerin toplamı 13 olduğundan, faktör analizi için gerekli örneklem büyüklügüne ilişkin asgari şartlara ulaşıldığ görülmektedir.

Anket formu; girişimcilerin ön bilgilerine, risk alma eğilimlerine ve girişimcilik fırsatlarının tanımlarına yönelik ölçekler ile birlikte demografik özelliklere yönelik ifadelerden oluşmaktadır. Girişimcilerin ön bilgileri; Wang vd. (2013)'nin, Ozgen (2003)'in araştırmasına dayanarak seçtikleri -biri ters kodlu olmak üzere- toplam 3 ifade ile ölçülmüştür. Risk alma eğilimi değişkeninin ölçümü için Yılmaz ve Sünbül (2009)'ün girişimcilik ölçeğinde yer alan ve Bilge ve Bal (2012) tarafindan yapılan faktör analizi neticesinde 'risk alma' olarak adlandırılan boyuttaki 7 ifade kullanılmıştır. Son olarak girişimcilik firsatlarını tanıma değişkeninin ölçümü için ise Ozgen ve Baron (2007)'un araştırmalarında kullandıkları 3 ifadeden faydalanılmıştır. Tamamı likert tarzda olan ölçeklerde, girişimci adaylarının ifadelere katılım düzeyleri " $1=$ Hiç Katılmıyorum"dan "5=Kesinlikle Katılıyorum”a doğru beş basamakta sıralanarak ölçülmüştür.

\section{3. Ön Analizler}

Dağıtılan 250 adet formundan; katılımcıların bir ya da birden çok değişkenle ilgili ifadelere katılım düzeylerini tamamen boş bıraktıkları, anket formundaki ifadelerin tamamına ya da büyük bölümüne aynı cevabı verdikleri, zikzak şeklindeki yanıtlar gibi anlamsız veriler içeren anketler araştırma kapsamının dişında tutulmuş (Leiner, 2013), 144 adet anket formunun analize dahil edilmesi uygun görülmüştür. $\mathrm{Bu}$ veri seti içerisinde, katılımcıların likert tarzdaki ifadelerden toplam 12 adedine cevap vermedikleri görülmüş, cevapsız bırakılan ifadelerin anket formundaki toplam ifadelerin \%10'unun altında olması sebebiyle, bu ifadelere bulundukları grubun ortalamaları yazılarak verilerin tamamı analize uygun hale getirilmiştir (Mertler ve Vannatta, 2005: 36-37).

Gerçekleştirilecek analizler için bir gereklilik olan normallik varsayımına ilişkin olarak; Shapiro-Wilks ve Kolmogrov-Smirnov testleri gerçekleştirilmiş, test sonuçlarına göre verilerin normal dağılımdan anlamlı şekilde farklılık göstermediği anlaşılmıştır. Ayrıca ortalama, medyan ve mod değerlerinin birbirine 
yakın olduğu, ayrıca basıklık ve çarpıklık değerlerinin ağırlıklı olarak \pm 3 aralığında olduğu görülmüştür (Kalaycı, 2009). Az sayıdaki verinin basıklık değerlerinin \pm 4 aralığında olmasına rağmen, bu değerin üst sınırı için \pm 7 aralığının işaret edildiği dikkate alınarak (Bollen ve Paxton, 1998: 266-268), basıklık değerlerin aşırılaşmadığı kanaatine varılmıştır. Son olarak histogram grafikleri de verilerin normal dağılıma yakınsadığını desteklemiştir.

Olası bir ortak yöntem sapması problemi için de Harman'1n tek faktör testi (Podsakoff vd., 2003: 879-882) uygulanmıştır. Ölçekteki tüm ifadeler döngüsüz faktör analizine sokulmuş, öz değeri 1'den büyük olan toplam 4 boyut belirlenmiş ve birinci boyutun toplam varyansın \%39'unu açıkladığı görülmüştür. Dolayısıyla bu çalışmada ortak yöntem sapması sorununun olmadığ 1 kanaati oluşmuştur.

\section{Bulgular}

\subsection{Demografik Özellikler}

Katılımcıların demografik özellikleri incelendiğinde; \%95.1'inin $(n=137)$ daha önce bir iş yerinde çalışmış olduğu, \%75.7'sinin $(\mathrm{n}=109)$ maaşlı olarak, \%19.4'ünün ( $\mathrm{n}=28)$ girişimci olarak çalıştığı görülmüştür (7 katılımcı bu soruya cevap vermemiştir).

Tablo 1: Katılımcıların Demografik Özellikleri

\begin{tabular}{|c|c|c|c|c|c|}
\hline$\ddot{O ̈ z e l l i k l e r}$ & $n$ & $\%$ & $\ddot{O ̈ z e l l i k l e r}$ & $n$ & $\%$ \\
\hline Iss tecrübesi & & & Şu anki çaltşma durumu & & \\
\hline Daha önce çalışmış & 137 & 95.1 & Çalışıyor & 59 & 41 \\
\hline $\begin{array}{l}\text { Daha önce hiç } \\
\text { çalışmamıș }\end{array}$ & 7 & 4.9 & Çalışmıyor & 85 & 59 \\
\hline Daha önceki çalışma şekli & & & Medeni durum & & \\
\hline Kendi işi & 28 & 19.4 & Evli & 89 & 61.8 \\
\hline Çalışan olarak & 109 & 75.7 & Bekar & 55 & 38.2 \\
\hline Cevap vermeyen & 7 & 4.9 & Cinsiyet & & \\
\hline Yaş aralı̆̆ & & & Kadın & 85 & 59 \\
\hline $18-24$ aras1 & 32 & 22.2 & Erkek & 59 & 41 \\
\hline $25-31$ aras 1 & 40 & 27.8 & Ĕ̆gitim durumu & & \\
\hline $32-38$ arasi & 39 & 27.1 & İlköğretim mezunu & 19 & 13.2 \\
\hline $39-45$ aras 1 & 21 & 14.6 & Lise mezunu & 44 & 30.5 \\
\hline 46 ve üzeri & 12 & 8.3 & Ön lisans mezunu & 24 & 16.7 \\
\hline & & & $\begin{array}{l}\text { Lisans ya da lisansüstü } \\
\text { mezunu }\end{array}$ & 52 & 36.1 \\
\hline
\end{tabular}

Katılımcıların \%41'inin $(\mathrm{n}=59)$ anketi cevapladıkları dönemde aktif olarak çalıştıkları görülmüştür. Eğitim durumuna bakıldığında katılımcıların \%43.8'inin $(n=63)$ lise ve altı seviyesinde, \%52.8'inin $(n=76)$ önlisans ya da lisans 
seviyesinde, kalan \%3.5'inin $(\mathrm{n}=5)$ ise lisansüstü seviyede eğitim aldıkları görülmüştür. Yaş aralıkları itibariyle katılımcıların \%22.2'si $(\mathrm{n}=32)$ 18-24, \%27.8'i (n=40) 25-31, \%27.1'i $(n=39)$ 32-38, \%14.6's1 $(n=21)$ 39-45 yaş aralığında olup, kalan $\% 8.3^{\prime}$ ü $(n=12)$ ise 46 ve daha büyük yaştadır. \%59'unu $(n=85)$ kadınların oluşturduğu katılımcıların \%61.8'i evlidir $(n=89)$. Katılımcıların demografik özellikleri Tablo 1'de toplu halde yer almaktadır.

\subsection{Açıklayıcı Faktör Analizi, Geçerlilik ve Güvenirlik}

Araştırma kapsamında kullanılan ölçeklerin yapısal geçerliliklerini değerlendirmek üzere açıklayıcı faktör analizi gerçekleştirilmiştir (Şencan, 2005: 776). Veri setinin faktör analizine uygunluğu için KMO katsayısı ile birlikte Bartlett küresellik testine odaklanılmış, sonuçlar itibariyle verilerin analize uygun olduğu anlaşılmıştır.

Açıklayıcı faktör analizi neticesinde, girişimcinin ön bilgileri boyutuna ait 3 ifade, beklendiği gibi tek boyutta toplanmıştır. Risk alma değişkenine ait 7 ifadeden birinin aynı anda iki faktör altında yer aldığı (binişik olduğu) ve güvenirlik analizi sonucunda ölçekten çıkarılmasının güvenirliği artıracağı görülmüştür. Dolayısıyla bu ifade ("Üzerinde çalıştığım bir konuda hata yapmaktan çekinmem") analizden çıkarılmıştır. Benzer şekilde girişimcilik fırsatlarını tanıma içerisindeki ifadelerden birinin ("Potansiyel yeni girişim fırsatlarını kendiliğimden göremiyorum") faktör yükünün düşük olması ve ölçekten çıkarılmasının güvenirliği artıracağı görülerek, ilgili ifade analiz kapsamına alınmamıştır. Söz konusu ifadelerin çıkarılması ile faktör yüklerinin tamamı, Hair vd. (2005: 777)'nin tavsiye ettikleri düzeyden (>.50) yüksek seviyede hesaplanmıştır. İfadeler arasındaki korelasyon değerlerinin, birleşme geçerliliğini (Şencan, 2005: 799); değişkenler arasındaki korelasyon değerlerinin ise ayrışma geçerliliğini destekler nitelikte olduğu görülmüştür (Hair vd., 2005: 778). Ölçeklere ilişkin açıklayıcı faktör analizi sonuçları, Tablo 2'de yer almaktadır.

Tablo 2: Ölçeklere İlişkin Açıklayıcı Faktör Analizi Sonuçları

\begin{tabular}{lcccc}
\hline \multicolumn{1}{c}{ Ölçekler } & Faktör Yükleri & $\begin{array}{c}\text { Açıklanan } \\
\text { Varyans (\%) }\end{array}$ & $\begin{array}{c}\text { Cronbach Alfa } \\
\text { Katsayıs }\end{array}$ \\
\hline Girişimcinin & .82 & & 66.08 & .74 \\
Ön Bilgileri & .82 & & & \\
& .80 & & & \\
Risk Alma & & .84 & 56.22 & .83 \\
& & .82 & & \\
& & .79 & & \\
& & .73 & & \\
& & .69 & & \\
Girişimcilik & & .61 & & \\
Firsatların1 & & .93 & 86.43 & \\
Tanıma & & .93 & & \\
\hline
\end{tabular}


Araştırma kapsamında kullanılan ölçeklerin güvenirlikleri Cronbach Alfa katsayı ile ölçülmüştür. Gerçekleştirilen analizler sonucunda Cronbach Alfa katsayılarının girişimcinin ön bilgileri değişkeni için .74, risk alma değişkeni için .83 ile yeterli düzeyde olduğu değerlendirilmiştir (Nunnally ve Bernstein, 1994). Girişimcilik firsatlarını tanıma ölçeği iki ifadeden oluştuğu için güvenirliğinin Cronbach Alfa katsayısı yerine standardize edilmiş Cronbach Alfa katsayısı ile test edilmesi tavsiye edilmiştir (Eisinga vd., 2013: 638). Söz konusu değer de .84 olarak hesaplanmıştır.

\subsection{Korelasyon ve Regresyon Analizleri}

Araştırma kapsamındaki üç değişkenin aralarındaki ilişkilerin yönünü ve gücünü görebilmek için korelasyon analizi gerçekleştirilmiştir. Tablo 3 'te yer alan sonuçlara göre girişimcilik fursatlarını tanımanın, risk almayla ve girişimcilerin ön bilgileriyle arasındaki ilişkiler pozitif yönlü ve orta derecededir (sırasıyla r:.41, $\mathrm{p}<.01$ ve $\mathrm{r}: .55, \mathrm{p}<.01)$. Araştırmanın bağımsız değişkenleri olan risk alma ve girişimcilik fırsatlarını tanıma arasındaki ilişki de pozitif yönde ve benzer güçtedir $(\mathrm{r}: .45, \mathrm{p}<.01)$.

Tablo 3: Değişkenler Arası Korelasyon Katsayıları

\begin{tabular}{llll}
\hline \multicolumn{1}{c}{ Değişkenler } & $\begin{array}{l}\text { Girişimcinin } \\
\text { Ön Bilgileri }\end{array}$ & $\begin{array}{l}\text { Risk } \\
\text { Alma }\end{array}$ & $\begin{array}{l}\text { Girişimcilik } \\
\text { Fırsatlarını Tanıma }\end{array}$ \\
\hline $\begin{array}{l}\text { Girişimcinin Ön } \\
\text { Bilgileri }\end{array}$ & 1 & & \\
Risk Alma & $.55^{*}$ & 1 & \\
Girişimcilik & $.41^{*}$ & $.45^{*}$ & 1 \\
Fırsatlarını Tanıma & & & \\
\hline$* \mathrm{p}<.01$ & &
\end{tabular}

Risk alma ve girişimcinin ön bilgilerinin, girişimcilik firsatlarını tanıma üzerindeki etkisinin tespiti için doğrusal regresyon analizi yapılmıştır. 1.97 olarak hesaplanan Durbin Watson katsayısının 2,5'un altında olması (Durbin ve Watson, 1951), değişkenler arasında otokorelasyon probleminin olmadığını; 1.42 olarak hesaplanan VIF değeri de çoklu doğrusal bağlantı sorunu olmadığını göstermektedir. Tablo 4'te yer alan regresyon sonuçlarına göre model anlamlı olup, $(\mathrm{F}=22.41 ; \mathrm{p}<.01)$; modelin $\mathrm{R}^{2}$ değeri. 24'tür (düzeltilmiş $\mathrm{R}^{2}=.23$ ).

Tablo 4: Ölçeklere İlişskin Açıklayıcı Regresyon Analizi Sonuçları

\begin{tabular}{|c|c|c|c|c|c|c|c|}
\hline $\begin{array}{l}\text { Băğımsız } \\
\text { Değişken }\end{array}$ & $B$ & $\begin{array}{l}\text { Standart } \\
\text { Hata }\end{array}$ & $\beta$ & $t$ & $p$ & Tolerans & $V I F$ \\
\hline Sabit & 1.13 & .45 & - & 2.51 & $.013 *$ & - & - \\
\hline Ön Bilgi & .30 & .12 & .23 & 2.58 & $.011^{*}$ & .70 & 1.42 \\
\hline Risk Alma & .39 & .10 & .33 & 3.77 & $.000 * *$ & .70 & 1.42 \\
\hline
\end{tabular}


Regresyon analizi sonuçlarına göre risk alma ve girişimcinin ön bilgileri, girişimcilik fırsatlarını tanımadaki varyansın \%24'lük kısmını açıklamaktadır. Risk almanın $(\beta=.33, p=.00)$ ve girişimcinin ön bilgilerinin $(\beta=.23, p=.01)$ girişimcilik firsatlarını tanıma üzerinde pozitif yönde etkili oldukları görülmüştür. Analiz sonuçlarından hareketle " $\mathrm{H}_{1}$ : Ön bilgi ile girişimcilik firsatlarını tanıma arasında pozitif yönlü ve istatistiki olarak anlamlı bir ilişki bulunmaktadır." ve " $\mathrm{H}_{2}$ : Risk alma eğilimi ile girişimcilik firsatlarını tanıma arasında pozitif yönlü ve istatistiki olarak anlamlı bir ilişki bulunmaktadır." hipotezleri desteklenmiştir.

Son olarak, " $\mathrm{H}_{3}$ : Girişimcilik fırsatlarını tanıma, eğitim durumuna göre farklılık göstermektedir." hipotezi incelenmiştir. Bunun için başlangiçta tek yönlü ANOVA analizi yapılmasına karar verilmiştir. Ancak Tablo 1'de görüldüğü üzere eğitim durumu, 5 seçenek ile ölçülmüştür. Katılımcılar eğitim durumlarına göre gruplandıklarında, toplam 3 gruptaki katılımcı sayısının tek yönlü ANOVA analizi için yeterli sayıda olmadığı görülmüştür. Dolayısıyla Kruskal-Wallis testinin uygulanmasına karar verilmiştir. Kruskal-Wallis testi sonucuna göre girişimcilik firsatlarını tanıma, eğitim durumuna göre farklılık göstermemektedir, $\chi 2(3)=3.53, \mathrm{p}=0.32$. Dolayısıyla $\mathrm{H}_{3}$ hipotezi desteklenmemiştir.

\section{Sonuç ve Değerlendirme}

Günümüzde girişimciliğin artan önemi ve rolü göz önüne alındığında, yeni girişimcilik fırsatlarının nasıl geliştirildiğini ve bireysel farklılıkların bu fırsatların keşfedilmesinde nasıl bir rol oynadığını anlamak önem kazanmaktadır. $\mathrm{Bu}$ çalışmada, Avusturya iktisat teorisinden ve bilişsel teoriden hareketle, girişimci adaylarının ön bilgilerinin ve risk alma eğilimlerinin, girişimcilik firsatlarını tanıma düzeyleri üzerindeki etkisinin tespit edilmesi amaçlanmıştır. Ayrıca, girişimcilik fırsatlarını tanımanın, eğitim durumuna göre farklılık gösterip göstermediği de araştırılmıştır.

Regresyon analizi sonucu elde edilen bulgulara göre, girişimcinin sahip olduğu ön bilgi, girişimcilik firsatlarını tanıma üzerinde pozitif yönlü ve istatistiki olarak anlamlı şekilde etkilidir. Bu sonuç, girişimcilik fırsatlarını tanıma sürecinin dayandığ teorilerden olan bilişsel teori ve Avusturya iktisat teorisinin öne sürdüğ̈ varsayımlar ile paraleldir. Fırsat tanıma sürecinin bireye özgü bilişsel bir durum olduğunu ifade eden bilişsel teori, girişimcilerin firsatları tanımlarken bilişsel önsezilerini kullandıklarını ve bu girişimcilerin mevcut ön bilgilerinin (prior-knowledge) firsatların tanınmasına yardımcı olduğunu farz eder. Aynı şekilde, Avusturya iktisat teorisi de piyasada diğer bireylerin sahip olmadığı bilgiye haiz girişimcilerin firsatları tanımlayabildiği ve ayrıca bu firsatları kullanabildiğini varsayar. Beklendiği üzere, bu çalışma kapsamında elde edilen bulgular; Shane (2000), Ko ve Butler (2006), Shepherd ve DeTienne (2005), Hajizadeh ve Zali (2016) ile Ardichvili vd. 'nin (2003) bulguları ile de örtüşmektedir. Yani girişimci adayının sahip olduğu ön bilgiler girişimcilik firsatlarını tanımasını olumlu yönde etkilemektedir. 
$\mathrm{Bu}$ çalışmada, girişimcilik fırsatlarını tanımayı etkilediği varsayılan diğer bir değişken risk alma eğilimidir. BRisk alma eğiliminin, girişimcilik fırsatlarını tanımayı pozitif yönlü ve istatistiki olarak anlamlı şekilde etkilediği görülmüştür. $\mathrm{Bu}$ sonuç da risk alma ile girişimcilik fırsatlarını tanıma arasındaki ilişkiyi inceleyen diğer çalıșmalarda (Krueger ve Dickson,1994; Lunnan vd., 2006; Özkul ve Dulupçu, 2014) elde edilen bulgular ile benzerlik göstermektedir. Buna göre girişimci adaylarının risk alma eğilimi, girişimcilik fırsatlarını tanımalarını olumlu yönde etkilemektedir.

Araştırmanın son bulgusu, girişimcilik fırsatlarını tanımanın, eğitim durumuna göre farklllık göstermediği yönündedir. Bu noktadan hareketle, girişimcilik fırsatlarını tanımanın eğitim durumundan ziyade spesifik olarak girişimcilik konulu eğitimlerle ilişkili olabileceği dikkate alınmalıdır. Dolayısıyla girişimci adaylarının, girişimcilik ve bağlantılı konulardaki bilgi birikimlerini artırmaları önerilmektedir. Ayrıca ileride yapılacak çalışmalarda girişimcilik fırsatları kategorize edilerek, farklı türlerdeki girişimcilik firsatlarının eğitim durumu ile ilişkisi araştırılabilir.

Girişimci adaylarının mevcut ön bilgi düzeylerinin girişimcilik fırsatlarını tanıma seviyeleri üzerindeki olumlu etkisinden hareketle, girişimci adaylarının girişimcilik sürecine ilişkin bilgi birikimlerini artırmalarının önem arz ettiği söylenebilir. Girişimci adaylarının herhangi bir girişimcilik faaliyetine başlamadan önce; pazar, pazara giriş ve pazarda faaliyette bulunma şekilleri, tüketicilerin ihtiyaçlarını ve bu ihtiyaçlara yönelik uygun ürün ve hizmetleri belirleyebilme konularına yönelik bilgi birikimlerini genişletmelerinin faydalı olacağı düşünülmektedir (Ozgen, 2003; Shane, 2000; Venkataraman, 1997). Girişimci adaylarının iş ve özel yaşamlarını değişik tecrübeler ile zengin hale getirmeleri ve olabildiğince uygulamaya dönük ve yaparak öğrenmeyi temel alan tecrübeler edinmeleri önerilmektedir.

Risk alma davranışının girişimcilik fırsatlarını tanıma düzeyi üzerindeki pozitif etkisine yönelik olarak da girişimci adaylarının risk ve firsat arasındaki dengenin analizine itina etmeleri gerektiği görülmüştür. Girişimci adayları; firsatları değerlendirmenin yolunun risk almaktan geçtiğini dikkate alarak, nicel ve nitel karar verme teknikleri hususlarında bilgi edinmeli, taşınabilir ve anlamlı riskler almalıdırlar. KOSGEB gibi girişimcilik konusunda eğitim veren kurumların da eğitim konularını ve içeriklerini; uygulama odaklı, örnek vaka analizlerini içeren ve eğitime katılan girişimci adaylarının da interaktif bir biçimde eğitim faaliyetlerinde rol alabildiği, katılımcıların bilgi düzeylerini artırırken risk analizi yetkinliklerini de artıracak şekilde planlamaları önerilmektedir.

Araştırmanın yalnızca Adana ve Mersin illerinde uygulamalı girişimcilik eğitimine katılan girişimci adaylarına yönelik olması araştırmanın sınırlılığını oluşturmaktadır. İlerleyen zamanlarda yapılacak olan araştırmalarda, bu araştırmada ölçülen değişkenlerin farklı bölgelerden temin edilecek verilerle analizi neticesinde farklı sonuçlar ortaya koyup koymadığı ölçülebilir. Bu durum; 
araştırma sonuçlarının genellenmesi problemi açısından faydalı olacaktır. İleride yapılacak çalışmalarda, yurtdışında gerçekleştirilen araştırmalarda girişimcilik firsatlarını tanıma üzerinde etkili olduğu bulgulanan; girişimcinin yaratıcılık düzeyi, kendine güven düzeyi, sahip olduğu sosyal ağlar gibi değişkenleri de ele alan, daha kapsayıcı araştırma modelleri içeren çalışmalar yapılabilir.

\section{Kaynakça}

Aksay, B. ve İplik, E. (2014). Girişimcilik Eğilimi Ölçeğinin (GET 2) Türkiye Bağlamında Değerlendirilmesi. Çukurova Üniversitesi Sosyal Bilimler Enstitüsü Dergisi, 23(2), 199-210.

Ardichvili, A., Cardozo, R. ve Ray, S. (2003). A Theory of Entrepreneurial Opportunity Identification and Development. Journal of Business Venturing, 18(1), 105-123.

Baron, R. A. (1998). Cognitive Mechanisms in Entrepreneurship: Why And When Enterpreneurs Think Differently Than Other People. Journal of Business Venturing, 13(4), 275-294.

Baron, R. A. (2004). Opportunity Recognition: A Cognitive Perspective. Academy of Management Proceedings. August 1, 1-6.

Baron, R. A. (2006). Opportunity Recognition As Pattern Recognition: How Entrepreneurs 'Connect The Dots' To Identify New Business Opportunities. Academy of Management Perspective. 20(1), 104-119.

Baron, R. A. (2007a). Behavioral and Cognitive Factors in Entrepreneurship: Entrepreneurs as the Active Element in New Venture Creation. Strategic Entrepreneurship Journal, 1(1-2), 167-182.

Baron, R. A. (2007b). Opportunity Recognition As Pattern Recognition: How Entrepreneurs Connect The Dots To Identify New Opportunities. Academy of Management Perspectives. February, 104-119.

Baron, R. A. ve Ensley, M. D. (2006). Opportunity Recognition as The Detection of Meaningful Patterns: Evidence From Comparisons of Novice and Experienced Entrepreneurs. Management Science, 52(9), 1331-1344.

Bilge, H. ve Bal, V. (2012). Girişimcilik Eğilimi: Celal Bayar Üniversitesi Öğrencileri Üzerine Bir Araştırma. Süleyman Demirel Üniversitesi Sosyal Bilimler Enstitüsü Dergisi. 16(2), 131-148.

Bilgin, N. (2016). Sosyal Psikoloji Sözlüğü Kavramlar, Yaklaşımlar, 3. Baskl, Istanbul: Bağlam Yayınlart.

Bollen, K. A. ve Paxton, P. (1998). Interactions of Latent Variables in Structural Equation Models. Structural Equation Modeling: A Multidisciplinary Journal, 5(3), 267-293. 
Bluedorn, A. C. (2002). The Human Organization of Time: Temporal Realities and Experience. Stanford, CA: Stanford University Press.

Busenitz, L. W. ve Barney, J. B. (1997). Differences between Entrepreneurs and Managers in Large Organizations: Biases and Heuristics in Strategic DecisionMaking. Journal of Business Venturing, 12(1), 9-30.

Bygrave, W. D. ve Hofer, C. W. (1992). Theorizing About Entrepreneurship. Entrepreneurship Theory and Practice, 16(2), 13-22.

Carsrud, A. L. ve Johnson, R. W. (1989). Entrepreneurship: A Social Psychological Perspective. Entrepreneurship \& Regional Development, 1(1), 21-31.

De Carolis, D. M. ve Saparito, P. (2006). Social Capital, Cognition, and Entrepreneurial Opportunities: A Theoretical Framework. Entrepreneurship Theory and Practice, 30(1), 41-56.

Durbin, J. ve Watson, G. S. (1951). Testing For Serial Correlation İn Least Squares Regression. II. Biometrika, 38 (1/2), 159-177.

Dutta, D. K. ve Crossan, M. M. (2005). The Nature of Entrepreneurial Opportunities: Understanding the Process Using the 4i Organizational Learning Framework. Entrepreneurship Theory and Practice, 29(4), 425-449.

Eisinga, R., Te Grotenhuis, M. ve Pelzer, B. (2013). The Reliability Of A TwoItem Scale: Pearson, Cronbach, Or Spearman-Brown?. International Journal of Public Health, 58(4), 637-642.

Hair, J. F., Black, W. C., Babin, B. J., Anderson, R. E. ve Tatham, R. L. (2005). Multivariate Data Analysis. New Jersey: Pearson Prentice Hall

Hajizadeh, A. ve Zali, M. (2016). Prior Knowledge, Cognitive Characteristics and Opportunity Recognition. International Journal of Entrepreneurial Behavior \& Research, 22(1), 63-83.

Henrekson, M. (2007). Entrepreneurship and Institutions. Comparative Labour Law \& Policy Journal, 28(4), 717-742.

Hills, G. E. ve Shrader, R. C. (1998). Successful Entrepreneurs' Insights into Opportunity Recognition. Frontiers of entrepreneurship research, 18(2), 3041.

Kalaycı, Ş. (2009). SPSS Uygulamalı Çok Değişkenli Ístatistik Uygulamaları. Ankara: Asil Yayınevi

Kalfaoğlu, S. ve Öğe H. S. (2018). Frrsat Girişimcisinin Yeni Özelliği: Polikronisite. Girişimcilik ve Kalkınma Dergisi, 13(2), 166-182. 
Kalkan, M. ve Kaygusuz, C. (2012). The Psychology of Entrepreneurship. In Entrepreneurship-Born, Made and Educated. www.intechopen.com. (Erişim: 15.01.2019)

Karabey, C. N. ve Bingöl, D. (2010). Girişimciliğin Başlangıcı Olarak Fırsat Tanımlama. Istanbul Management Journal, 21(67), 9-31.

Karadal H.,(2014). Girişimcilik. Uygulamalı Girişimcilik Eğitimi ve Güncel Konular. Girişimci Destekleri ve İş Planı. 4. Baskı. İstanbul: Beta Yayınları.

Kirzner, I. M. (1997). Entrepreneurial Discovery and the Competitive Market Process: An Austrian Approach. Journal of Eeconomic Literature, 35(1), 6085.

Kline, R. (2013). Exploratory and Confirmatory Factor Analysis. (Ed.) Petscher, Y., Schatschneider, C. \& Compton, D. Applied Quantitative Analysis in Education and The Social Sciences. 169-207, New York: Routledge.

Ko, S. ve Butler, J. E. (2006). Prior Knowledge, Dissociative Mode of Thinking and Entrepreneurial Opportunity Identification. International Journal of Entrepreneurship and Small Business, 3(1), 3-16.

Krueger Jr, N. ve Dickson, P. R. (1994). How Believing in Ourselves Increases Risk Taking: Perceived Self-Efficacy and Opportunity Recognition. Decision Sciences, 25(3), 385-400.

Krueger, N.F. (2000). The Cognitive Infrastructure of Opportunity Emergence. Entrepreneurship Theory and Practice. 24(3), 5-23.

Kuratko, D. F. (2016). Entrepreneurship: Theory, Process, and Practice. Boston: Cengage Learning.

Leiner, D. J. (2013). Too Fast, Too Straight, Too Weird: Post Hoc Identification of Meaningless Data In Internet Surveys. https://doi.org/10.2139/ssrn.2361661, (Erişim: 05.01.2019).

Littunen, H. (2000). Entrepreneurship and the Characteristics of the Entrepreneurial Personality. International Journal of Entrepreneurial Behavior \& Research, 6(6), 295-310.

Lunnan, A., Nybakk, E. ve Vennesland, B. (2006). Entrepreneurial Attitudes and Probability for Start-Up: An Investigation of Norwegian Non-Industrial Private Forest Owners. FOREST policy and Economics, 8(7), 683-690.

Mertler, C. A. ve Vannatta, R. A. (2005). Advanced and Multivariate Statistical Methods: Practical Application And Interpretation, Glendale: Pyrczak Publishing. 
Mitchell, R. K., Busenitz, L., Lant, T., McDougall,P.P., Morse, E.A. ve Smith, J.B., (2002). Toward A Theory of Entrepreneurial Cognition: Rethinking the Side of Entrepreneurship. Entrepreneurship Theory and Practice, 27(2), 93104.

Nunnally, J.C. ve Bernstein, I.H. (1994). Psychometric Theory. Third Ed. New York: McGraw-Hill.

Ozgen, E. (2003). Entrepreneurial Opportunity Recognition: Information Flow, Social and Cognitive Perspective. Unpublished Doctoral Dissertation, Rensselaer Polytechnic Institute, Troy University, New York.

Ozgen, E. ve Baron, R. A. (2007). Social Sources of Information in Opportunity Recognition: Effects of Mentors, Industry Networks, and Professional Forums. Journal Of Business Venturing, 22(2), 174-192.

Özkul, G. ve Dulupçu, M. A. (2014). TR61 Bölgesinde Girişimsel Fırsat Tipleri ve Belirleyici Unsurları: Kirzneryen Fursatlara Karş1 Schumpeteryen Fursatlar. Alanya Işletme Fakültesi Dergisi, 6(2), 131-151.

Podsakoff, P. M., Mackenzie, S. B., Lee, J. Y.ve Podsakoff, N. P. (2003). Common Method Biases in Behavioral Research: A Critical Review of the Literature and Recommended Remedies. Journal of Applied Psychology. 88(5), 879-903.

Renko, M., Shrader, R. C. ve Simon, M. (2012). Perception of Entrepreneurial Opportunity: A General Framework. Management Decision, 50(7), 12331251.

Ronstadt, R. (1988). The Corridor Principle. Journal of Business Venturing, 3(1), 31-40.

Sarason, Y., Dean, T., ve Dillard, J.F. (2005). Entrepreneurship as the Nexus of İndividual and Opportunity: A Structuration View. Journal of Business Venturing, 21, 286-305.

Sarasvathy, D. K., Simon, H. A.,ve Lave, L. (1998). Perceiving and Managing Business Risks: Differences between Entrepreneurs and Bankers. Journal of Economic Behavior \& Organization, 33(2), 207-225.

Schumpeter, J., (1934). Capitalism, Socialism, and Democracy. New York: Harper \& Row.

Shane, S.A. (2000). Prior Knowledge and the Discovery of Entrepreneurial Opportunities. Organization Science, 11 (4), 448-69.

Shane, S. ve Venkataraman, S. (2000). The Promise of Entrepreneurship as a Field of Research. Academy of Management Journal. 25(1), 217-226. 
Shepherd, D. A. ve DeTienne, D. R. (2005). Prior Knowledge, Potential Financial Reward, and Opportunity Identification. Entrepreneurship Theory and Practice, 29(1), 91-112.

Simon, M., Houghton, S. M., \& Aquino, K. (2000). Cognitive Biases, Risk Perception, and Venture Formation: How Individuals Decide To Start Companies. Journal of business venturing, 15(2), 113-134.

Stevenson, H.H., Roberts, M.J. ve Grousbeck, H.I. (1985). New Business Ventures Aand the Entrepreneur. Irwin: Homewood.

Şencan, H. (2005). Sosyal ve Davranışsal Ölçümlerde Güvenilirlik ve Geçerlilik. Ankara: Seçkin Yayıncılık.

Tomak, S.(2011). Girişimcilik ve Bilişsel Yanlılık. Girişimcilik ve Kalkınma Dergisi. 6(1), 71-95.

Ucbasaran, D., Westhead, P. ve Howorth, C. A. (2000). Habitual Entrepreneurs: Human Capital, Opportunity Search and Learning. Frontiers of Entrepreneurship Research. At: www.babson.edu/entrep/fer/I/IF/IF.htm, (Erişim: 19.01.2019).

Venkataraman, S. (1997). The Distinctive Domain of Entrepreneurship Research. Advances In Entrepreneurship, Firm Emergence And Growth, 3(1), 119-138.

Wang, Y. L., Ellinger, A. D. ve Jim Wu, Y. C. (2013). Entrepreneurial Opportunity Recognition: An Empirical Study of R\&D Personnel. Management Decision, 51(2), 248-266.

Yılmaz, E. ve Sünbül, A. M. (2009). Üniversite Öğrencilerine Yönelik Girişimcilik Ölçeğinin Geliştirilmesi. Selçuk Üniversitesi Sosyal Bilimler Enstitüsü Dergisi, 21(2), 195-203 